\title{
Strategic voting in a bicameral setting*
}

\author{
Simon $\operatorname{Hug}^{\dagger}$ \\ Département de science politique, Université de Genève
}

\author{
Paper prepared for presentation at the conference \\ "Reform processes and policy change: How do veto players \\ determine decision-making in modern democracies" \\ University of Mannheim, May 14-16, 2009
}

First preliminary draft (usual health warnings apply) May 4, 2009

\begin{abstract}
Recent work on roll call votes has demonstrated the importance of considering more explicitly the agenda tree that leads to the votes considered. When doing so, the issue of whether members of parliament behave sincerely or in a sophisticated manner comes to the forefront. While a series of studies have, on the basis of examples mostly taken from the US Congress, tried to analyze with the help of theoretical models sophisticated voting, few studies have considered this type of voting in a bicameral setting. The present paper proposes a game-theoretic model of sophisticated voting in a bicameral parliament. Assuming incomplete information on the preferences across the two chambers, the analysis demonstrates that in bicameral settings sophisticated voting cannot be considered chamber by chamber, but has to be analyzed in the context of the whole voting process.
\end{abstract}

* Some early thoughts of this paper were presented at a seminar at the University of Mannheim and at the Annual Meeting of the Midwest Political Science Association in Chicago (April 2-5, 2009). I wish to thank the participants at these events as well as Bjørn Hoyland for the very helpful comments and the Swiss National Science Foundation (Grant No 100012111909) for its generous funding.

† Département de science politique, Faculté des sciences économiques et sociales; Université de Genève; 40, Bd du Pont d'Arve; 1211 Genève 4; Switzerland; phone ++41 2237983 78; email: simon.hug@unige.ch 


\section{Introduction}

Research on parliaments has made tremendous progress on the one hand by making theoretical advances for a better understanding of members of parliament' (MPs) behavior (e.g., Londregan, 2000; Clinton and Meirowitz, 2004; Cox and McCubbins, 2005; Carey, 2008) and on the other in the empirical analysis of roll call votes (e.g., Martin and Quinn, 2002; Clinton, Jackman and Rivers, 2004; Poole, 2005). A careful reading of these two branches of the literature suggests, however, a potential (and most likely real) problem. The work by Londregan (2000), Clinton and Meirowitz (2004), Cox and McCubbins (2005) and Carey (2008) (see also, e.g. Rosenthal and Voeten, 2004; Spirling and McLean, 2006; Carrubba, Gabel and Hug, 2008) suggests that votes in parliament have to be considered as embedded in the larger process of law-making. Important in this context are also, as Clinton and Meirowitz (2004) suggest, aspects of strategic voting. Currently employed techniques to analyze roll call votes do, however, not consider this embedded nature of votes in parliaments (for exceptions, see Londregan, 2000; Clinton and Meirowitz, 2004). Given this, it is unclear what currently used techniques for roll call analyses actually tell us about MPs.

Interest in strategic voting by MPs has, however, ebbed (mostly) and flowed. Many scholars have found comfort in Krehbiel and Rivers's (1990) critique of work on strategic voting in parliaments, arguing that in the absence of a fixed agenda and partial information on the preferences of MPs strategic voting is unlikely to occur. In many parliaments aside Congress, however, fixed agendas and information provided by political parties are more likely to prevail (see for instance Bütikofer and Hug, 2008). A largely neglected aspect regarding strategic voting relates, however, to the chamber structure. Strictly speaking the analysis of strategic voting as championed by McKelvey and Niemi (1978) (based on Farquharson, 1969) and more or less applied by, for instance, Bjurulf and Niemi (1978), Enelow and Koehler (1980), Enelow (1981), Denzau, Riker and Shepsle (1985), Calvert and Fenno (1994) relies on a final vote occurring in a given chamber. If this is the case as in much of Bjurulf and Niemi's (1978) analysis, proceeding this way causes no problems. In bicameral settings, like the US congress (Enelow and Koehler, 1980; Enelow, 1981; Denzau, Riker and Shepsle, 1985; Krehbiel and Rivers, 1990; Calvert and Fenno, 1994) or the Swiss parliament (Bütikofer and Hug, 2008) an analysis of strategic voting only makes 
sense when considering the bicameral sequence and voting procedure 1

In the present paper, drawing on Martin's (2001) model and offering some initial results from a game with incomplete information, I wish to discuss the conditions under which strategic behavior across chambers may occur and, as a consequence, affect our analyses of roll call data. Under certain conditions concerning the agenda power of the two chambers sophisticated voting by MPs is expected under rather mild conditions. If agenda powers are vested, however, in both chambers the analysis suggests that sophisticated behavior, while still possible at the MP-level, is more likely, as suggested by Krehbiel and Rivers (1990), off the floor of parliament, for instance in committees and in party caucauses.

In the next section I review the literature on roll call votes as it relates to bicameral parliamentary settings. Drawing on this discussion I briefly discuss different bicameral settings as they set the context in which sophisticated behavior may occur in section three. Section four is devoted to a theoretical analysis exploring the conditions under which sophisticated voting could occur in a bicameral structure. Finally, section five discusses these results, while section six concludes.

\section{Roll call votes, sophisticated behavior and bi- cameral parliaments}

The analysis of roll call votes in parliaments has progressed considerably over the last decades or so. On the one hand the methodological sophistication has increased dramatically, as the recent work by, among others, Heckman and Snyder (1997), Poole (2000), Bailey and Chang (2001), Martin and Quinn (2002), and Clinton, Jackman and Rivers (2004) (for a review see Poole, 2005) demonstrates. On the other hand, while initially very focused on analyses of the US Congress, roll call votes are used as empirical material increasingly also in comparative research (see for example Carey, 2008).$^{2}$

Much of this research, however, has not spent much time reflecting on the context in which roll call votes occur. First, and foremost, roll call votes may

\footnotetext{
${ }^{1}$ Interesting none of the classical works on Congress deals or even mentions this complication, with the sole exceptions, to my knowledge, of the contribution of Martin (2001).

${ }^{2}$ Comparative, in this context, may mean both work on parliaments other than the US Congress, and work comparing different legislatures.
} 
only form a very selective subset of all votes taken in a parliament, and this subset, as more and more empirical evidence suggests, may bias our inferences (e.g., Carrubba, Gabel, Murrah, Clough, Montegomery and Schambach, 2006; Roberts, 2007; Carrubba, Gabel and Hug, 2008; Chiou and Yang, 2008; Hug, 2009 (forthcoming); Thiem, 2009). The strongest empirical evidence for such biases appears in Roberts (2007) and Hug (2009 (forthcoming)) who can show for the US Congress, respectively the Swiss parliament, that behavior in roll call votes differs systematically compared to behavior in other votes.

Second, as work for instance by Londregan (2000), Martin (2001), Clinton and Meirowitz (2004), Bütikofer and Hug (2008) and Hoyland and Hagemann (2009 (forthcoming)) shows, roll call votes take place in a specific decision-making process, and as much analyses of roll call votes consider them as independent observations, this context may again bias our inferences $3^{3}$ This decision-making context determines on the one hand what votes will be taken on the floor (and thus potentially observed as roll call votes) (e.g., Londregan, 2000; Clinton, 2006; Penn, 2008) through various gate-keeping powers, 4 and on the other hand lead to sophisticated behavior by MPs (e.g., Volden, 1998; Martin, 2001; Clinton and Meirowitz, 2004; Bütikofer and Hug, 2008; Penn, 2009)

While work on sophisticated behavior in parliaments has seen a series of theoretical (e.g., McKelvey and Niemi, 1978; Enelow and Koehler, 1980; Enelow, 1981; Denzau, Riker and Shepsle, 1985; Calvert and Fenno, 1994) and empirical contributions (e.g., Bjurulf and Niemi, 1978) in the aftermath of Farquharson (1969) seminal work, a critical article by Krehbiel and Rivers (1990) has largely (and for a considerable time) put a lid on studying sophisticated voting in parliaments 5 Their critique of work on sophisticated behavior by MPs largely focuses on the following points. For MPs being able to engage in sophisticated behavior, first, the agenda has to be fixed, and second, the MPs need to be reasonably well informed on the preferences of their colleagues. Discussing this issue in the con-

\footnotetext{
${ }^{3}$ Related to this problem is obviously the effect of party discipline, which may lead to odd estimates of ideal-points based on roll call votes (see Rosenthal and Voeten, 2004; Spirling and McLean, 2006, 2007).

${ }^{4}$ See, however, Martin and Quinn's (2005) argument that at least Bayesian ideal-point estimates of Supreme Court justices are not unduly affected by the latter's gate-keeping powers.

${ }^{5}$ Only recently, a series of scholars is attempting to identify instances of strategic behavior (e.g., Jenkins and Munger, 2003; Finocchiaro and Jenkins, 2008; Leemann, 2009). See also the related litterature on log-rolling nicely reviewed by Stratmann (1997), who also devises a test for cycling behavior in parliaments (Stratmann, 1996).
} 
text of the US Congress they argue that the important malleability of the agenda on the floor simply makes sophisticated behavior unlikely. Much more likely, according to them, is sophisticated behavior before votes occur on the floor, either through gate-keeping (see for instance Clinton, 2006) or agenda-control (see for instance Cox and McCubbins, 2005). And if sophisticated voting is occurring all the same on the floor, it will often be observationally equivalent to sincere behavior ("sophisticated sincerity" in Austen-Smith's (1987) terms) (for the theoretical basis, see Austen-Smith, 1987).

While this criticism may well apply to the US Congress (though see Calvert and Fenno, 1994; Martin, 2001; Clinton and Meirowitz, 2004), it is far from certain that it implies the absence of all sophisticated floor behavior in parliaments around the world. Quite to the contrary, agenda control by political parties and the role of information provider of the latter suggest that especially in parliamentary systems sophisticated behavior may well be quite frequent (see for instance Bütikofer and Hug, 2008).

Most work on sophisticated behavior relies implicitly (or explicitly) on McKelvey and Niemi's (1978) work, which based on Farquharson's (1969) seminal contribution proposes to analyze voting in terms of "sophisticated equivalents." Hence, working back through the agenda-tree, each alternative is replaced by the outcome of the tree starting at the branches of the respective decisions. This implies, however, that the ultimate decision-node is well identified (in addition to the points raised by Krehbiel and Rivers (1990)). As almost all empirical (and theoretical analyses) focus on a single chamber, however, this ultimate decisionnode may not be as easily identified, or even be uncertain, for instance through because of the possible use of conciliation committees in case of bicameral disagreement $]^{6}$ Hence, ignoring the bicameral context may bias our analyses of sophisticated behavior on the chamber floors, especially if they rely in one way or the other on the idea of "sincere preferences" finding their expression in chamber final passage votes (except, obviously, on reports from the conciliation committee or on bills already adopted in the other chamber).

This bicameral context is, however, almost completely ignored. Perhaps, many scholars agree with McCarty and Cutrone (2006) who conclude their survey

\footnotetext{
${ }^{6}$ The only model dealing with this aspect that I am aware of, namely Martin's (2001), "solves" this problem by having an exogenous bill adopted if a conciliation committee needs to be called (see below for more details).
} 
chapter on bicameralism by stating that

"[w] hen viewed through the tools of contemporary legislative analysis - spatial, multilateral bargaining, and informational models - the case for bicameralism seems less than overwhelming. Even in models where bicameralism might have an effect, we find that the necessary conditions for such an effect are empirically rare. Further, much of the empirical evidence of the policy effects bicameralism is either weak or attributable to either malapportionment or supermajoritarianism, outcomes that could theoretically be produced in unicameral legislatures."

Their conclusion is based on a discussion of a selected set of theoretical contribution: $\Omega^{7}$ and an argument that the results of many empirical studies cannot really attribute a "causal effect" to the chamber structure 8 Probably, implicitly relying on this conclusion, few scholars have considered the bicameral structure when analyzing roll call votes. At most, a series of authors attempted to sharpen our understanding of roll call votes by comparing them across chambers for various empirical analyses (see for instance Levitt, 1996; Bailey and Chang, 2001; Hug, 2005; Bailey, 2007).

As a sole exception appears Martin's (2001) work that considers sophisticated voting in a separation of powers system, and thus by implication in a bicameral parliament.9 His model presumes that a congressman has to vote on an exogenous bill $A$, knowing that another chamber has still a say, and both a president and the supreme court may invalidate the adopted bill. In case of a rejection, the status quo $Q$ is the outcome, while in case of acceptance a compromise adopted (implicitly) by the conciliation committee will result. Analyzing this simple game in a one-dimensional policy space, Martin (2001) can derive implications concerning the likelihood of sophisticated behavior (distinguishing it also from "sophisticated sincerity") and finds considerable empirical support from empirical data

\footnotetext{
${ }^{7}$ For instance, they fail to consider Martin's (2001) work on sophisticated behavior in a bicameral setting.

${ }^{8}$ See Heller (2007) for a review focusing on the empirical results (e.g., Levmore, 1992; Heller, 2001; Congleton, 2003).

${ }^{9}$ Interesting to note is that Martin's (2001) article is almost exclusively cited (at least according to Google Scholar) by scholars dealing with the Supreme Court. For one reason or another, this important contribution has not found an audience among congressional (or legislative) scholars.
} 
on the US Congress ${ }^{10}$ The main limitation of Martin's (2001) model stems from the quite constraining assumptions on which it is built. First of all, the agenda in this game is fixed with exogenously given alternatives, and the role of the conciliation committee in case of disagreement between the chambers is rather arbitrary. Second, the information available to the main player in this game is complete and perfect. Hence, by assumption, Martin (2001) deals with a situation, which in the eyes of Krehbiel and Rivers (1990) may allow for sophisticated behavior, but should not apply to the US Congress ${ }^{11}$ Despite these limitations, his model provides a fruitful starting point, also to assess different institutional setups, discussed in the next section.

\section{$3 \quad$ Bicameral settings}

Bicameralism differs in practice considerably in terms of the distribution of powers.12 Implicit in Martin's (2001) model is a bicameral system in which one chamber has the proposal right, and diverging bills automatically lead to the adoption of a compromise bill, in which the difference between the two chambers are split 13 Work on bicameral parliaments (e.g., Trivelli, 1974; Tsebelis and Money, 1997; Patterson and Mughan, 1999) suggests, however, that there is a wide variety of arrangements, which may even differ according to the policy field.

Given Martin's (2001) model especially three elements seem important (at least for what follows). First of all, is one chamber limited in its proposal rights (which is implicit in Martin's (2001) model)? Second, in case of bicameral dis-

\footnotetext{
${ }^{10}$ In some sense related is Hoyland and Hagemann's (2009 (forthcoming)) study on bicameralism in the European Union. They can demonstrate that Council votes (i.e., votes in the upper house) affect the way in which the European parliament (the lower house) votes. While their focus is on the particuliarities of the so-called co-decision procedure, their work still suggests that separate analyses of one chamber may be misleading.

${ }^{11}$ In his empirical analysis, however, Martin (2001) attempts to deal with the first point by limiting his analysis also on a subset of votes where the assumption largely holds, and the results carry over.

${ }^{12}$ McCarty and Cutrone (2006), in their review chapter on bicameralism, adopt an unnecessarily stringent definition of bicameralism by limiting it to parliaments where the two chambers have equal powers. Obviously, such a stringent definition, if applied stringently, would eliminate almost all bicameral systems from consideration (for a description of the wide diversity of bicameral competencies, see Trivelli, 1974; Tsebelis and Money, 1997; Patterson and Mughan, 1999).

${ }^{13}$ This is very similar to Tsebelis and Money's (1997) setup, where the bargain of the conciliation committee is characterized with the Nash bargaining solution (for the relationship between the mean and the Nash bargaining solution see Achen, 2006).
} 
agreement, is there a conciliation committee which may propose a compromise proposal? Third, are the proposals endogenous or not?

In terms of the first criteria we may distinguish the following sets:

- Bicameral parliaments where one of the chambers only has the right to veto (but in some cases may be overridden). Examples: British House of Lords, European Parliament in the case of the ascent procedure (see Hix, 2005), the Dutch upper house (see Timmermans, Scholten and Oostlander, 2008), the German Bundesrat in the case of Einspruchsgesetze (see Ismayr, 2008) etc.

- Bicameral parliaments where both chambers have the right to amend proposals and their agreement is required. Examples: German parliament in the case of Zustimmungsgesetze (see Ismayr, 2008), US Congress, Swiss parliament (see Jegher, 1999), European parliament in the case of co-decision (see Hix, 2005) 14

These two sets may be further subdivided according to the other two criteria. For each combination, however, clearly empirical examples may be found (see Tsebelis and Money, 1997; Patterson and Mughan, 1999).

\section{Sophisticated voting in a bicameral setting: theory}

In this section I explore two simple setups, one relying on Martin's (2001) model, to assess under what conditions sophisticated voting in a bicameral system may occur, both under complete (as in Martin's (2001) model) and incomplete information.

\subsection{Complete information}

The starting point of the complete information setup is Martin's (2001) model of strategic voting in a separation of powers system. His model is based on a one-dimensional policy space, over whose elements actors have single-peaked

\footnotetext{
${ }^{14}$ Though see Hoyland and Hagemann's (2009 (forthcoming)) analysis suggesting that the Council has in this case conditional agenda-setting control (for a related argument concerning the cooperation procedure but regarding the EP, see Tsebelis, 1994).
} 
preferences (linear tent-preferences). In his setup apart a legislator and an "other chamber" two additional actors are present, namely a president and a judiciary. For simplicity, and since my focus is on bicameralism, I omit the latter two actors.

Based on this simplification, the sequence of play is as follows:

1. An exogenous bill $A$ ( $A<Q$ where $Q$ is the status quo) is presented.

2. Member $C$ with ideal-point $x_{C}$ votes for $A$ or $Q$. If she votes for $Q$ the game ends, and the status quo $Q$ is maintained.

3. If $C$ votes for $A$ the compromise bill of the conciliation committee between $A$ and the other chamber's preferred policy $x_{O}$, i.e. $\frac{A+x_{O}}{2}$ results.

In this setup the decision of $C$, and more specifically whether she will vote sincerely or sophisticatedly, depends on the preference configurations. Her utility from the two options are the following:

$$
\begin{aligned}
E U_{C}(A) & =-\left|x_{C}-\frac{x_{O}+A}{2}\right| \\
E U_{C}(\neg A) & =-\left|x_{C}-Q\right|
\end{aligned}
$$

Hence, $C$ will vote "sophisticatedly" for $A$ if the following condition holds:

$$
\begin{aligned}
& p(A)=1 \text { if } E U_{C}(A) \geq E U_{C}(\neg A) \\
& p(A)=1 \text { if }-\left|x_{C}-\frac{x_{O}+A}{2}\right| \geq-\left|x_{C}-Q\right|
\end{aligned}
$$

The following four situations exhaust all preference configurations under the assumptions of the game:15

a) $x_{C} \leq \frac{x_{O}+A}{2}$ and $x_{C} \leq Q$

In that case $C$ votes sincerely for $A$ as long as $x_{C} \leq \frac{A+Q}{2}$ and sophisticatedly for $A$ if $Q \geq \frac{x_{O}+A}{2}$.

Hence differences between sincere and sophisticated behavior appear if

\footnotetext{
${ }^{15}$ The detailed derivations for the results appear in the appendix.
} 
i) $x_{C} \leq \frac{A+Q}{2}$ and $Q<\frac{x_{O}+A}{2}$ (sincere vote $A$, sophisticated vote $Q$ ).

ii) $x_{C}>\frac{A+Q}{2}$ and $Q \geq \frac{x_{O}+A}{2}$ (sincere vote $Q$, sophisticated vote A).

b) $x_{C}>\frac{x_{O}+A}{2}$ and $x_{C}>Q$

Under these conditions $C$ votes sincerely always for $Q$ and sophisticatedly for $A$ if $Q<\frac{x_{O}+A}{2}$

Hence differences between sincere and sophisticated behavior appear if

i) $Q<\frac{x_{O}+A}{2}($ sincere vote $Q$, sophisticated vote $A$ )

c) $x_{C} \leq \frac{x_{O}+A}{2}$ and $x_{C}>Q$

Under these conditions $C$ votes sincerely always for $Q$ and sophisticatedly for $A$ if $Q \leq 2 x_{C}-\frac{x_{O}+A}{2}$

Hence differences between sincere and sophisticated behavior appear if

i) $Q \leq 2 x_{C}-\frac{x_{O}+A}{2}$ (sincere vote $Q$, sophisticated vote $A$ )

d) $x_{C}>\frac{x_{O}+A}{2}$ and $x_{C} \leq Q$

In that case $C$ votes sincerely for $A$ as long as $x_{C} \leq \frac{A+Q}{2}$ and sophisticatedly for $A$ if $Q>2 x_{C}-\frac{x_{O}+A}{2}$.

Hence differences between sincere and sophisticated behavior appear if

i) $x_{C} \leq \frac{A+Q}{2}$ and $Q \leq 2 x_{C}-\frac{x_{O}+A}{2}$ (sincere vote $A$, sophisticated vote $Q$ ).

ii) $x_{C}>\frac{A+Q}{2}$ and $Q>2 x_{C}-\frac{x_{O}+A}{2}$ (sincere vote $Q$, sophisticated vote A).

Figure 1 illustrates the preference configurations under the four scenarios that lead to sophisticated behavior. In situation $a$ ) there are two sets of preference configurations for $C$ and $O$ that lead to sophisticated behavior. The first one, depicted above the line, leads to a sincere vote by $C$ for $A$ but a sophisticated vote for $Q$. In the preference configuration depicted below the line the sincere and sophisticated votes are inversed. Under conditions $b$ ) the preference configurations leading to differences between sincere and sophisticated behavior are of one type, as depicted in panel $b$ ) of figure 1. For conditions $c$ ) again only one set of preference configurations leads to a sincere vote for $A$ and a sophisticated vote for $Q$ as depicted in panel $c$ ) of figure 1. Finally, in the last configuration $(d)$ ) again two preference configurations would generate differences between sincere 
Figure 1: Conditions under which $C$ 's sophisticated voting differs from sincere voting

a)

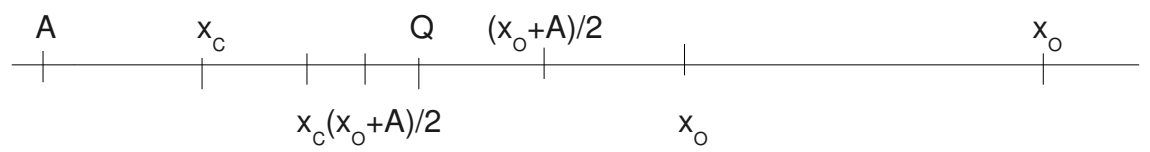

b)

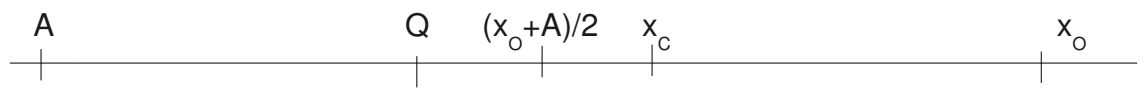

c)

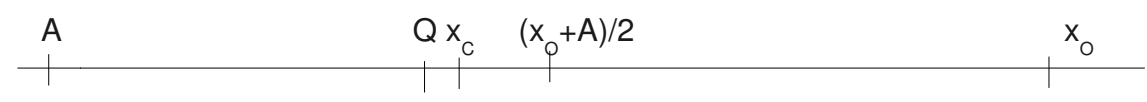

d)

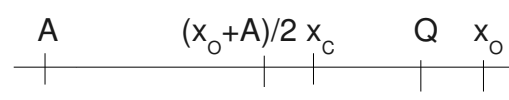

and sophisticated voting. The set depicted in panel $d$ ) generates a sincere vote $Q$ and a sophisticated vote for $A$, while an extreme value for $x_{O}$ to the left of $A$ would generate the inverse pattern.

The added value in terms of implications of these results compared to Martin's (2001) is limited if non-existent. They underline again that preference divergences between $C$ and the other chamber drive sophisticated behavior of $C$ that is observably different from sincere behavior.

Considering now as illustrations a set of institutional variations based on the discussion above we can consider the following additional situations.

First, consider a situation where again the agenda is exogenously fixed, both chambers vote according to a closed rule and there is no conciliation committee. The sequence of play looks as follows: 
1. An exogenous bill $A$ is presented with $A<Q$ where $Q$ is the status quo.

2. Member $C$ with ideal-point $x_{C}$ votes for $A$ or $Q$.

3. The median voter of the other chamber with ideal-point $x_{O}$ votes for $A$ or $Q$.

4. If both chambers accept $A$, the latter option becomes law, if one of them rejects $Q$ results.

In this scenario, quite clearly, $C$ will never engage in sophisticated voting. A weakly dominant strategy, whatever the preference configuration, is to vote for her preferred alternative.

Next consider a situation where there is an endogenous agenda, closed rule in the other chamber and no conciliation committee.

In that case the situation looks like a simple veto player argument (Tsebelis, 1995), where the agenda-setter (i.e., the first chamber) adopts the most preferred bill that is still acceptable to the other chamber.

Finally, consider a situation where there is also an endogenous agenda, closed rule in the other chamber, but where there also exists a conciliation committee.

In that case $C$ votes for $A$ or $Q$ if other chamber agrees with $A, A$ is adopted if not compromise bill $\frac{x_{O}+A}{2}$ is submitted to both chambers ${ }^{16}$

\subsection{Incomplete information}

A simple way to address the issue of incomplete information is to rely on the one hand on McKelvey and Niemi's (1978) work on sophisticated equivalents and employ some of the basic insights presented by Enelow (1981) ${ }^{17}$

For simplicity assume that two proposals $A_{1}$ and $A_{2}$ are voted upon to replace the status quo $Q$. As an illustration, consider the situation where chamber 1 has the preference order $A_{1}>A_{2}>Q$ while chamber 2 has either $A_{2}>Q>A_{1}$ or $A_{2}>A_{1}>Q$. The prior belief of chamber $1(p(Q))$ corresponds to the probability that chamber 2 has the first preference ordering and $1-p(Q)$ that it will be the second ordering.

\footnotetext{
${ }^{16}$ It may seem odd, that $C$ does not vote on the proposal of the conciliation committee. Such a vote, however, is anticipated by the $C$ in its decision to vote for $A$, hence adding such a vote would be redundant.

${ }^{17}$ This part of the paper is still rather sketchy.
} 
Consider the following sequence of play

- Chamber 1 votes $A_{1}$ against $A_{2}$ and then the winner against $Q$.

- Provided one of the proposals beats $Q$ the second chamber votes in the same sequence. If both adopt the same bill, the latter is the end result, if not the status quo $Q$ will prevail.

In this case chamber 1 expected utility for the two votes is the following:

$$
\begin{aligned}
& E U_{1}\left(\text { voting } A_{1}\right)=(p(Q) * U(Q))+(1-p(Q)) * U\left(A_{1}\right) \\
& E U_{1}\left(\text { voting } A_{2}\right)=U\left(A_{2}\right)
\end{aligned}
$$

This is obviously exactly the same setup as Enelow and Koehler's (1980), suggesting that sophisticated voting will occur depending on the prior belief of chamber 118 What this setup allows, however, is to consider strategic voting both under the assumption of signaling (Banks, 1991) and screening (Calvert, 1986).19

\section{Discussion}

The rather limited theoretical glimpses at sophisticated voting in a bicameral setting suggests that the bicameral sequence of decision-making cannot be simply ignored. Martin's (2001) model, and the extensions presented here, show that sophisticated voting is quite likely across chambers. This even more so, when incomplete information is assumed, as Enelow's (1981) model dealing with a unicameral setting does.

Martin's (2001) model, except one extension presented above, and Enelow's (1981) setup, are, however, limited in several regards. While their strength is the demonstration that sophisticated behavior may occur in bicameral settings, these results are obtained with fixed agendas (in both cases cases) and perfect knowledge of the preferences of all actors involved (in Martin's (2001) model). In a bicameral setting, however, as the one extension briefly discussed above, sophisticated voting is also possible if one chamber has agenda control and the other chamber has only veto power 20 More difficult seems to be, from a theoretical point of view, a situation where both chambers have agenda control and

\footnotetext{
${ }^{18}$ In Enelow and Koehler's (1980) the prior beliefs concern the behavior of other members of the same chamber.

${ }^{19}$ These aspects will be developed in future versions of this paper.

${ }^{20}$ As the discussion above showed, empirical examples for such a distribution of powers exist.
} 
possible intercameral disagreements are settled by a conciliation committee. In that case only very late in the game is the agenda tree sufficiently fixed to allow for observable sophisticated behavior. The conditions under which such behavior should be expected still needs to be theoretically analyzed.

Comfort can be found, however, in the empirical evidence presented by Martin (2001). His analyses, though they only constitute an indirect test, suggest that even in the "inhospitable" environment of the US congress sophisticated voting across chambers seems to be occurring.

\section{Conclusion}

The main contention of this paper is that roll call votes do not occur in a vacuum. While a series of scholars has already raised this point, few have considered an important aspect of parliament, namely its cameral structure. Bi- or multicameral structures create conditions for additional sophisticated behavior, which has not been dealt with sufficiently so far.

Simple theoretical models suggest, however, that conditions allowing for such behavior may very well exist. These conditions depend, however, very much on the distribution of powers across chambers. Hence, if these conditions are likely to be fulfilled, also the bicameral structure of parliaments may raise doubts about the insights simple-minded analyses of roll call votes generate.

Consequently, roll call vote analyses, whether in terms of ideal-point estimations or party cohesion, has to consider the context of the floor voting much more in detail to be sure that the inferences we draw are not systematically biased. 


\section{Appendix}

Below I present the more detailed calculations to determine the conditions under which $C$ votes for $A$ in the four different preference configurations (see above) ${ }^{21}$

a) $x_{C} \leq \frac{x_{O}+A}{2}$ and $x_{C} \leq Q$

In that case $C$ votes for $A$

$$
\begin{aligned}
x_{C}-\frac{x_{O}+A}{2} & \geq x_{C}-Q \\
\rightarrow Q & \geq \frac{x_{O}+A}{2}
\end{aligned}
$$

b) $x_{C}>\frac{x_{O}+A}{2}$ and $x_{C}>Q$

In that case $C$ votes for $A$

$$
\begin{aligned}
\frac{x_{O}+A}{2}-x_{C} & \geq Q-x_{C} \\
\rightarrow Q & \leq \frac{x_{O}+A}{2}
\end{aligned}
$$

c) $x_{C} \leq \frac{x_{O}+A}{2}$ and $x_{C}>Q$

In that case $C$ votes for $A$

$$
\begin{aligned}
x_{C}-\frac{x_{O}+A}{2} & \geq Q-x_{C} \\
\rightarrow Q & \leq 2 x_{C}-\frac{x_{O}+A}{2}
\end{aligned}
$$

d) $x_{C}>\frac{x_{O}+A}{2}$ and $x_{C} \leq Q$

In that case $C$ votes for $A$

$$
\begin{aligned}
\frac{x_{O}+A}{2}-x_{C} & \geq x_{C}-Q \\
\rightarrow Q & >2 x_{C}-\frac{x_{O}+A}{2}
\end{aligned}
$$

\footnotetext{
${ }^{21}$ This section will be extended in a future version.
} 


\section{References}

Achen, Christopher H. 2006. Institutional Realism and Bargaining Models. In The European Union Decides, ed. Robert Thomson, Frans N. Stokman, Christopher Achen and Thomas König. Cambridge: Cambridge University Press.

Austen-Smith, David. 1987. "Sophisticated Sincerity: Voting over Endogenous Agendas." American Political Science Review 81(4):1323-1329.

Bailey, Michael. 2007. "Comparable Preference Estimates across Time and Institutions for the Court, Congress and Presidency." American Journal of Political Science 51(3):433-448.

Bailey, Michael and Kelly Chang. 2001. "Comparing Presidents, Senators, and Justices: Inter-Institutional Preference Estimation." Journal of Law, Economics and Organization 17(2):477-506.

Banks, Jeffrey S. 1991. Signaling Games in Political Science. Chur: Harwood Academic Publishers.

Bjurulf, Bo H. and Richard G. Niemi. 1978. "Strategic Voting in Scandinavian Parliaments." Scandinavian Political Studies 1(1):5-22.

Bütikofer, Sarah and Simon Hug. 2008. "Strategic Behavior in the Swiss Parliament." Paper prepared for presentation at the Anual Meeting of the American Political Science Association, Boston, August 27-31, 2008.

Calvert, Randall L. 1986. Models of Imperfect Information in Politics. Chur: Harwood Academic Publishers.

Calvert, Randall L. and Richard F. Jr. Fenno. 1994. "Strategy and Sophisticated Voting in the Senate." Journal of Politics 56(2):349-376.

Carey, John M. 2008. Legislative Voting and Accountability. New York: Cambridge University Press.

Carrubba, Clifford J., Matthew Gabel, Lacey Murrah, Ryan Clough, Elizabeth Montegomery and Rebecca Schambach. 2006. "Off the Record: Unrecorded Legislative Votes, Selection Bias, and Roll-Call Vote Analysis." British Journal of Political Science. 
Carrubba, Clifford J., Matthew Gabel and Simon Hug. 2008. "Legislative Voting Behavior, Seen and Unseen: Adjusting for Selection Effects in Roll Call Vote Analysis." Legislative Studies Quarterly 33:543-572.

Chiou, Fang-Yi. and Wanying Yang. 2008. "Strategic Choices of Roll Call Requests." Paper presented at the annual meeting of the MPSA Annual National Conference, Palmer House Hotel, Hilton, Chicago, IL.

Clinton, Joshua D. 2006. "Testing Lawmaking Theories with (Endogenous) Roll Calls, 90th - 106th U.S. House." Department of Politics Princeton University.

Clinton, Joshua D. and Adam Meirowitz. 2004. "Testing Explanations of Strategic Voting in Legislatures: A Reexamination of the Compromise of 1790." American Journal of Political Science 48(4):675-689.

Clinton, Joshua D., Simon Jackman and Doug Rivers. 2004. "The Statistical Analysis of Roll Call Voting: A Unified Approach." American Political Science Review 98(2):355-370.

Congleton, Roger D. 2003. On the Merits of Bicameral Legislatures: Policy Predictability Within Partisan Polities. In Year Book of New Political Economy Vol. 22, ed. M. J. Holler, H. Kliemt, D. Schmidtchen and M. E. Streit. Tübingen: Mohr Siebeck pp. 29-49.

Cox, Gary W. and Mathew D. McCubbins. 2005. Setting the Agenda: Responsible Party Government in the U.S. House of Representatives. Cambridge: Cambridge University Press.

Denzau, Arthur, William H. Riker and Kenneth A. Shepsle. 1985. "Farquharson and Fenno: Sophisticated Voting and Home Style." American Political Science Review 79(4):1117-1134.

Enelow, James M. 1981. "Saving Amendments, Killer Amendments, and an Expected Utility Theory of Sophisticated Voting." Journal of Politics 43:10621089.

Enelow, James M. and David H. Koehler. 1980. "The Amendment in Legislative Strategy: Sophisticated Voting in the U.S. Congress." Journal of Politics 5:396-413. 
Farquharson, Robin. 1969. Theory of Voting. New Haven: Yale University Press.

Finocchiaro, Charles J. and Jeffrey A. Jenkins. 2008. "In Search of Killer Amendments in the Modern U.S. House." Legislative Studies Quarterly 33:263-294.

Heckman, James J. and James M. Jr. Snyder. 1997. "Linear Probability Models of the Demand for Attributes with an Empirical Application to Estimating the Preferences of Legislators." The Rand Journal of Economics 28(0 special issue):S142-S189.

Heller, William B. 2001. "Political Denials: The Policy Effect of Intercameral Partisan Differences in Bicameral Parliamentary Systems." Journal of Law, Economics and Organization 17(1):34-61.

Heller, William B. 2007. "Divided Politics: Bicameralism, Parties, and Policy in Democratic Legislatures." Annual Review of Political Science 10:245-269.

Hix, Simon. 2005. The Political System of the European Union (2nd Edition). New York: St. Martin's Press.

Hoyland, Bjorn and Sara Hagemann. 2009 (forthcoming). "Bicameral Politics in the Euopean Union." Journal of Common Market Studies .

Hug, Simon. 2005. "The Swiss Upper House. "Chambre de Réflexion" or Conservative Renegades.” Zürich: unpublished paper, IPZ, Universtität Zürich.

Hug, Simon. 2009 (forthcoming). "Selection Effects in Roll Call Votes." British Journal of Political Science .

Ismayr, Wolfgang. 2008. Gesetzgebung im politischen System Deutschlands. In Gesetzgebung in Westeuropa : EU-Staaten und Europäische Union, ed. Wolfgang Ismayr. Wiesbaden: VS Verlag für Sozialwissenschaften pp. 383-429.

Jegher, Annina. 1999. Bundesversammlung und Gesetzgebung. Der Einfluss von institutionellen, politischen und inhaltlichen Faktoren auf die Gesetzgebungstätigkeit der Eidgenössischen Räte. Bern: Haupt.

Jenkins, Jeffery A. and Michael C. Munger. 2003. "Investigating the Incidence of Killer Amendments in Congress." Journal of Politics 65:498-517. 
Krehbiel, Keith and Douglas Rivers. 1990. "Sophisticated Voting in Congress: A Reconsideration." Journal of Politics 52:548-578.

Leemann, Lucas. 2009. "Catch me if you can. Recovering sophisticated voting in the lower house of Switzerland." Paper prepared for the Annual Swiss Political Science Meeting, St.Gallen January 2009.

Levitt, Steven D. 1996. "How Do Senators Vote? Disentangling the Role of Voter Preferences, Party Affiliation, and Senator Ideology." American Economic Review 86(3):425-441.

Levmore, Saul. 1992. "Bicameralism: When are Two Decisions Better Than One?" International Review, of Law and Economics 12:145-162.

Londregan, John. 2000. Legislative Institutions and Ideology in Chile. New York: Cambridge.

Martin, Andrew D. 2001. "Congressional Decision Making and the Separation of Powers." American Political Science Review 95(2):361-378.

Martin, Andrew D. and Kevin M. Quinn. 2002. "Dynamic Ideal Point Estimation Via Markov Chain Monte Carlo for the U.S. Supreme Court, 1953-1999." Political Analysis 10:134-153.

Martin, Andrew D. and Kevin M. Quinn. 2005. "Can Ideal Point Estimates be Used as Explanatory Variables?" Washington University and Harvard University.

McCarty, Nolan and Michael Cutrone. 2006. Does bicameralism matter? In The Oxford Handbook of Political Economy, ed. Barry R. Weingast and Donald A. Wittman. Oxford: Oxford University Press pp. 357-372.

McKelvey, Richard D. and Richard G. Niemi. 1978. "A Multistage Game Representation. of Sophisticated Voting for Binary Procedures." Journal of Economic Theory 18:1-22.

Patterson, Samuel Charles and Anthony Mughan, eds. 1999. Senates: Bicameralism in the Contemporary World. Columbus: Ohio State University Press. 
Penn, Elizabeth Maggie. 2008. "A distributive N-amendment game with endogenous agenda formation." Public Choice 136(1):201-213.

Penn, Elizabeth Maggie. 2009. "A Model of Farsighted Voting." American Journal of Political Science 53(1):36-54.

Poole, Keith. 2000. "Nonparametric Unfolding of Binary Choice Data." Political Analysis 8(3):211-237.

Poole, Keith. 2005. Spatial Models of Parliamentary Voting. New York: Cambridge University Press.

Roberts, Jason M. 2007. "The Statistical Analysis Of Roll-Call Data: A Cautionary Tale." Legislative Studies Quarterly 32:341-360.

Rosenthal, Howard and Erik Voeten. 2004. "Analyzing Roll Calls with Perfect Spatial Voting." American Journal of Political Science 48:620-632.

Spirling, Arthur and Iain McLean. 2006. "The Rights and Wrongs of Roll Calls." Government and Opposition 41(4):581-588.

Spirling, Arthur and Iain McLean. 2007. "UK OC OK? Interpreting Optimal Classification Scores for the U.K. House of Commons." Political Analysis 15(1):85-96.

Stratmann, Thomas. 1996. "Instability in Collective Decisions? A Test for Cyclical Majorities." Public Choice 88:15-28.

Stratmann, Thomas. 1997. Logrolling. In Perspectives on Public Choice. A Handbook, ed. Dennis C. Mueller. Cambridge: Cambridge University Press.

Thiem, Janina. 2009. Nationale Parteien im Europischen Parlament. Delegation, Kontrolle und politischer Einfluss. Wiesbaden: VS Verlag.

Timmermans, Arco, Peter Scholten and Steven Oostlander. 2008. Gesetzgebung im Politischen System der Niederlande. In Gesetzgebung in Westeuropa: EUStaaten und Europische Union, ed. Wolfgang Ismayr. Wiesbaden: VS Verlag fr Sozialwissenschaften. 
Trivelli, Laurent. 1974. Le bicamérisme: institutions comparées. Etude historique, statistique et critique des rapports entre le Conseil National et le Conseil des Etats. Lausanne: Université de Lausanne.

Tsebelis, George. 1994. "The Power of the European Parliament as a Conditional Agenda Setter." American Political Science Review 88(1):128-142.

Tsebelis, George. 1995. "Decision Making in Political Systems: Veto Players in Presidentialism, Parliamentarism, Multicamerialism and Multipartyism." British Journal of Political Science 25:289-325.

Tsebelis, George and Jeanette Money. 1997. Bicameralism. New York: Cambridge University Press.

Volden, Craig. 1998. "Sophisticated Voting in Supermajoritarian Settings." Journal of Politic 60(1):149-173. 